\begin{tabular}{|c|c|}
\hline Title & Reverse water gas shift reaction using supported ionic liquid phase catalysts \\
\hline Author(s) & Y asuda, Tomohiro; Uchiage, Eriko; Fujitani, Tadahiro; Tominaga, Ken-ichi; Nishida, May umi \\
\hline Citation & $\begin{array}{l}\text { A pplied Catalysis B-environmental, 232, 299-305 } \\
\text { https://doi.org/10.1016/.apcatb.2018.03.057 }\end{array}$ \\
\hline Issue Date & 2018-09-15 \\
\hline Doc URL & http:/hdl.handle.net/2115/79275 \\
\hline Rights & $\begin{array}{l}\text { () 2018. This manuscript version is made available under the CC-BY-NC-ND } 4.0 \text { license } \\
\text { http://treativecommons.org/icenses/by-nc-nd/4.0/ }\end{array}$ \\
\hline Rights(URL) & https://reativecommons.org/icenses/by-nc-nd/4.0/ \\
\hline Type & article (author version) \\
\hline Additional Information & There are other files related to this item in HUSCAP. Check the above URL. \\
\hline File Information & Revised_manuscript_for_RWGSR_using_SILP.pdf \\
\hline
\end{tabular}

Instructions for use 


\section{Reverse Water Gas Shift Reaction Using Supported Ionic Liquid Phase Catalysts}

Tomohiro Yasuda $^{1 *}$, Eriko Uchiage ${ }^{2}$, Tadahiro Fujitani ${ }^{2}$, Ken-ichi Tominaga $^{2}$, and Mayumi Nishida ${ }^{1,2}$

${ }^{1}$ Research and Development Division, Department of Practical Application, Institute for Catalysis, Hokkaido University, Kita 21, Nishi 10, Kita-ku, Sapporo 001-0021, Japan

2 Interdisciplinary Research Center for Catalytic Chemistry, National Institute of Advanced Industrial Science and Technology (AIST), Central 5-2, 1-1-1 Higashi, Tsukuba, Ibaraki 305-8565, Japan

*E-mail : t-yasuda@cat.hokudai.ac.jp

* To whom correspondence should be addressed.

Fax: +81-11-706-9381.

E-mail: t-yasuda@cat.hokudai.ac.jp 


\section{ABSTRACT}

The reverse water-gas shift reaction (RWGSR) using a supported ionic liquid-phase (SILP) catalyst consisting of Ru catalyst, ionic liquid (1-butyl-3-methylimidazolium chloride $\left(\left[\mathrm{C}_{4} \mathrm{mim}\right] \mathrm{Cl}\right)$ ), and porous silica gel support, was investigated. The catalytic activity of the SILP catalyst toward RWGSR strongly depends on the kind of Ru catalyst and amount of IL. Among the three kinds of Ru catalysts $\left(\left[\mathrm{RuCl}_{2}(\mathrm{CO})_{3}\right]_{2}, \mathrm{Ru}_{3}(\mathrm{CO})_{12}\right.$, and $\left.\mathrm{RuCl}_{3}\right),\left[\mathrm{RuCl}_{2}(\mathrm{CO})_{3}\right]_{2}$ exhibits the best catalytic activity. Brunauer-Emmett-Teller (BET) surface area analysis and diffuse reflectance infrared Fourier transform spectroscopy (DRIFTS) analyses of the SILP catalyst based on $\left[\mathrm{RuCl}_{2}(\mathrm{CO})_{3}\right]_{2}$ and $\left[\mathrm{C}_{4} \mathrm{mim}\right] \mathrm{Cl}$ revealed that both the solvation of the active catalytic Ru species and the surface area of the ionic liquid phase strongly affect catalytic activity. Hence, these factors help to determine the optimum amount of $\left[\mathrm{C}_{4} \mathrm{mim}\right] \mathrm{Cl}$ in the SILP catalyst. The resulting SILP catalyst, with an optimum constitution, exhibited greater catalytic activity than the homogeneous system in which the same amounts of $\left[\mathrm{RuCl}_{2}(\mathrm{CO})_{3}\right]_{2}$ and $\left[\mathrm{C}_{4} \mathrm{mim}\right] \mathrm{Cl}$ were employed. Catalytically active Ru species during RWGSR in both systems were investigated by means of electrospray ionization-mass spectrometry (ESI-MS). Interestingly, the rate-determining step in the two systems was different, implying that the silica support lowers the activation energy of the protonation reaction in the catalytic cycle. Therefore, the facilitation of the RWGSR by a SILP catalyst system can be realized by good mass transport, derived from the large surface area, as well as the effect of the silica support on activation energy. Furthermore, 20 cycles of the RWGSR using the SILP catalyst were 
accomplished. 


\section{Introduction}

Synthesis gas[1, 2], a mixture of carbon monoxide (CO) and hydrogen $\left(\mathrm{H}_{2}\right)$ that is industrially synthesized from natural gas or cokes, is a significant starting material in the field of C1 chemistry for the production of organic chemicals: not only methanol in large quantities, but also fine chemicals.[3-10] However, due to the highly toxic nature of CO, strict regulations have been imposed on its employment as a chemical source in industrial processes. This has necessitated the development of alternatives to $\mathrm{CO}$ as starting materials. Carbon dioxide $\left(\mathrm{CO}_{2}\right)$ has been recognized as a possible candidate, since it can be converted to CO by the reverse water-gas shift reaction (RWGSR: $\mathrm{CO}_{2}+\mathrm{H}_{2} \rightarrow \mathrm{CO}+\mathrm{H}_{2} \mathrm{O}$ ) and can also be easily obtained as exhaust gas from industrial and domestic buildings. RWGSR has been widely investigated by using heterogeneous supported metal catalysts such as $\mathrm{Pt}[11-14]$, Ni[15-18], $\mathrm{Cu} / \mathrm{Zn}[19-23], \mathrm{Au}[24-26], \mathrm{Fe}[27-30]$ and so on. In addition to these catalyst system, RWGSR utilizing solid oxide fuel cell system has been also investigated.[31] Most of these reactions, however, are carried out at elevated temperature over $300{ }^{\circ} \mathrm{C}$. On the other hand, some research groups have investigated RWGSR by using transition metal complex homogeneous catalysts of $\mathrm{Rh}[32]$ and $\mathrm{Ru}[33-35]$. These homogeneous catalysts can make RWGSR to proceed at relatively low temperature below $200{ }^{\circ} \mathrm{C}$.

In hydroformylation [36-39], an alkene reacts with synthesis gas in the presence of a catalyst to give an aldehyde or an alcohol which have one more carbon in their chemical structure than the starting alkene. Hence, this reaction has been widely explored for application to large-scale industrial chemical processes. Recently, Tominaga endeavored to develop an 
environmentally-friendly hydroformylation reaction using non-toxic $\mathrm{CO}_{2}$ instead of $\mathrm{CO}$, and reported that, by using the ruthenium cluster homogeneous catalyst $\mathrm{Ru}_{3}(\mathrm{CO})_{12}$, hydroformylation of various kinds of alkenes (1-hexene[40], cyclohexane[41], $\alpha$-methylstyrene[42] and so on) can proceed under a $\mathrm{H}_{2} / \mathrm{CO}_{2}$ mixed gas atmosphere. In these cases, the reaction initiates from $\mathrm{CO}$ evolution by the RWGSR and hydroformylation subsequently occurs.[41] An attractive feature of this one-pot reaction is that hydroformylation can proceed without any purification of the mixed gas resulting from the RWGSR; thus, the RWGSR and subsequent hydroformylation occur in the same reactor vessel, making this process a promising alternative to conventional CO-based industrial processes.

The concept of a supported ionic liquid phase (SILP), in which a thin film of an ionic liquid (IL) is immobilized on the surface of a porous support such as silica, and a homogeneous catalyst is dissolved as well as immobilized in this supported IL layer, was first proposed by Wasserscheid and his coworkers.[43] To date, they have actively investigated gas phase reactions such as hydroformylation [43-46], hydrogenation [47], the water-gas shift reaction [48, 49], and hydroaminomethylation [50] in flow processes using SILP catalysts. Generally, based on design possibility, homogeneous catalysts exhibit greater catalytic activity and selectivity than heterogeneous catalysts, while the latter offer greater ease of application in chemical processes such as separation and flow processes, and are thus suitable for industrial mass production. The nature of SILP catalysts, wherein a homogeneous catalyst in the dissolved state is immobilized in a thin IL layer on a support, combines the merits of both types of catalysts. Furthermore, due to the relatively 
large surface area of the support and the ultra-thin thickness of the IL layer (typically, several nanometers), the interface between the IL phase and the outer part (gas phase for gas-phase reactions, or dispersion medium for liquid-phase reactions), is quite large. This is advantageous for the effective utilization of the catalyst molecule as well as mass transport. Typically, a SILP catalyst is prepared by mixing a porous support with a solution of the catalyst, IL, and co-solvent, followed by drying to remove the co-solvent. The preparation of SILP catalysts is hence simpler than that of conventional immobilized catalysts, where the catalyst molecule is chemically anchored on the surface of the support. In this study, the RWGSR using a SILP catalyst is investigated.

\section{Experimental}

\subsection{Materials}

Tricarbonyldichlororuthenium(II) dimer $\left(\left[\mathrm{RuCl}_{2}(\mathrm{CO})_{3}\right]_{2}\right)$ and triruthenium dodecacarbonyl $\left(\mathrm{Ru}_{3}(\mathrm{CO})_{12}\right)$ were purchased from STREM Chemicals. Ruthenium trichloride $\left(\mathrm{RuCl}_{3}\right)$ was purchased from Sigma-Aldrich. 1-Butyl-3-methylimidazolium chloride $\left(\left[\mathrm{C}_{4} \mathrm{mim}\right] \mathrm{Cl}\right)$ was purchased from Tokyo Chemical Industry. Silica gel (Wakosil C-200) was purchased from Wako Pure Chemical Industries. $\left[\mathrm{RuCl}_{2}(\mathrm{CO})_{3}\right]_{2}$ was dried at $25^{\circ} \mathrm{C}$ under vacuum for one night. $\left[\mathrm{C}_{4} \mathrm{mim}\right] \mathrm{Cl}$ was also dried at r.t. under vacuum for one night, and its water content was confirmed to be less than 200 ppm by Karl Fischer titration (Metrohm, 899 coulometer). Wakosil C-200 was heated at $500{ }^{\circ} \mathrm{C}$ for $10 \mathrm{~h}$ under $\mathrm{N}_{2}$ atmosphere. $\left[\mathrm{RuCl}_{2}(\mathrm{CO})_{3}\right],\left[\mathrm{C}_{4} \mathrm{mim}\right] \mathrm{Cl}$ and Wakosil C-200 were stored in a $\mathrm{N}_{2}$ atmosphere glove box (oxygen content and dew point are controlled to be less than 5 ppm and 
$45{ }^{\circ} \mathrm{C}$, respectively.). Dichloromethylene (dehydrated super grade) was purchased from Kanto Chemical Co., Inc., and purified using the Nikko Hansen Glass Contour/Ultimate Solvent System 5S-AIT before use.

\subsection{Preparation of SILP catalysts}

The typical procedure is as follows. In the glove box, $\left[\mathrm{RuCl}_{2}(\mathrm{CO})_{3}\right]_{2}(60 \mathrm{mg}, 117 \mu \mathrm{mol})$ and $\left[\mathrm{C}_{4} \mathrm{mim}\right] \mathrm{Cl}(1.6 \mathrm{~g})$ were added to a three-necked flask equipped with a stirrer bar and a silicon cap, and the flask was then taken out from the glove box. $\mathrm{CH}_{2} \mathrm{Cl}_{2}$ was collected in a Schlenk tube directly from the solvent purification system under Ar atmosphere, and $15 \mathrm{~mL}$ of the $\mathrm{CH}_{2} \mathrm{Cl}_{2}$ was transferred to the three-necked flask using a syringe. The resulting suspension was stirred at $30{ }^{\circ} \mathrm{C}$ until the solid dissolved completely. In the glove box, Wakosil C-200 (10.0 g) was added to another three-necked flask equipped with a stirrer bar, three-way stop cock, and silicon cap, and the flask was taken out from the glove box. The $\mathrm{CH}_{2} \mathrm{Cl}_{2}$ solution was taken out from the former three-necked flask using a syringe and placed into the latter three-necked flask, which was equipped with a $\mathrm{N}_{2}$-filled balloon for controlling internal pressure. The resulting suspension was stirred for 10 min. A distillation system, consisting of a Liebig condenser, cold trap, $\mathrm{N}_{2}$ inlet, and vacuum pump, was connected to the three-necked flask under $\mathrm{N}_{2}$ atmosphere, and the suspension was slowly vacuumed by means of a diaphragm pump by heating at $30{ }^{\circ} \mathrm{C}$. After removing most of the $\mathrm{CH}_{2} \mathrm{Cl}_{2}$, the suspension became a powder, and the three-necked flask was vacuumed using a rotary oil pump to completely remove the $\mathrm{CH}_{2} \mathrm{Cl}_{2}$ from the SILP catalyst. After drying, the prepared SILP was stored 
in the glove box. Figure 1 shows the appearance of the SILP and the RWGSR using SILP in this study.

\subsection{Procedure of RWGSR and evaluation of catalytic activity}

The typical procedure of the RWGSR is as follows. The reaction was carried out in a 40 mL stainless-steel autoclave (Taiatsu Techno Corp. Tokyo, Japan). The SILP catalyst (1.0 g) was employed in each RWGSR test. The atmosphere of the autoclave was completely substituted to $\mathrm{CO}_{2}$ by repeating $\mathrm{CO}_{2}$ charge and discharge four times. Then, $2 \mathrm{MPa}$ of $\mathrm{CO}_{2}$ and $6 \mathrm{MPa}$ of $\mathrm{H}_{2}$ were introduced into the autoclave, which was tightly sealed to prevent leakage of gases during the reaction. The RWGSR was performed using an aluminum block heater (Chemist Plaza Chemi-Chemi-200, SIBATA, Saitama, Japan). The autoclave was heated to $170{ }^{\circ} \mathrm{C}$ for 30 min and maintained at $170{ }^{\circ} \mathrm{C}$ for another $10 \mathrm{~h}$. The RWGSR was then immediately quenched by immersing the autoclave in cold water. The reaction gas was recovered using a sampling bag equipped with an integrated flow meter (KOJIMA ACM-1A). The concentration of CO in the recovered gas was analyzed by gas chromatography (Shimadzu, Kyoto, Japan) and the total amount of CO was calculated from the concentration and total volume of the reaction gas. Catalytic activity was evaluated by turnover number (TON)[51], which was calculated by dividing the number of moles of generated $\mathrm{CO}$ by that of Ru atoms in the employed catalyst. 
The surface areas and pore volumes of the SILP catalyst were determined by the nitrogen adsorption/desorption method at $-196{ }^{\circ} \mathrm{C}$ using a volumetric unit (Micromeritics ASAP 2020). Prior to measurements, the sample was vacuumed at $150{ }^{\circ} \mathrm{C}$ for $10 \mathrm{~h}$ to remove water and volatile molecules from the surface of the sample. Infra-red (IR) measurement of the SILP catalyst was carried out by diffuse reflectance infrared Fourier transform spectroscopy (DRIFTS) technique using a Jasco FT/IR-4100 spectrometer (Jasco, Tokyo, Japan). For the measurement, Wakosil C-200, which was coated only by $\left[\mathrm{C}_{4} \mathrm{mim}\right] \mathrm{Cl}$, was prepared and employed as the reference sample. Electrospray ionization-mass spectrometry (ESI-MS) was carried out using a Waters ZQ-2000 mass spectrometer. For measurement, Ru species were eluted from the SILP catalyst after the reaction by adding methanol, following which the resulting solution was filtered using a polytetrafluoroethylene (PTFE) membrane filter (pore size $=0.2 \mu \mathrm{m})$.

\section{Results and discussion}

\subsection{Comparison of catalysts}

First, the catalytic activity of three kinds of Ru complexes, $\left[\mathrm{RuCl}_{2}(\mathrm{CO})_{3}\right]_{2}, \mathrm{Ru}_{3}(\mathrm{CO})_{12}$, and $\mathrm{RuCl}_{3}$, was compared. SILPs were prepared using each catalyst and $\left[\mathrm{C}_{4} \mathrm{mim}\right] \mathrm{Cl}[52]$, and the RWGSR was performed with various reaction times. Figure 2 shows a plot of TON as a function of reaction time. The employed catalysts exhibit quite different catalytic activities, in the following order: $\left[\mathrm{RuCl}_{2}(\mathrm{CO})_{3}\right]_{2}>\mathrm{Ru}_{3}(\mathrm{CO})_{12}>>\mathrm{RuCl}_{3}$. For $\mathrm{Ru}_{3}(\mathrm{CO})_{12}$, two SILPs with the same composition were prepared and the reproducibility of their TON values was confirmed, indicating the suitability 
of our SILP preparation process. In the case of $\left[\mathrm{RuCl}_{2}(\mathrm{CO})_{3}\right]_{2}$, the TON reached 241 within the first $10 \mathrm{~h}$. However, another $30 \mathrm{~h}$ were required to exceed 400. No carbonaceous species other than CO was observed at this point. This convex upward behavior may be due to the equilibrium of the water-gas shift reaction. At $170^{\circ} \mathrm{C}$, the change in the Gibbs free energy $(\Delta G)$ of the RWGSR is $22.66 \mathrm{~kJ} \mathrm{~mol}^{-1}$, and thus the partial pressure of $\mathrm{CO}$ at equilibrium can be calculated as $0.15 \mathrm{MPa}$ when the initial partial pressures of $\mathrm{H}_{2}$ and $\mathrm{CO}_{2}$ are $6 \mathrm{MPa}$ and $2 \mathrm{MPa}$, respectively. (see SI). On the other hand, a TON of 413 corresponds to a partial pressure of $0.46 \mathrm{MPa}$ (see SI). The nature of SILP catalysts in batch equipment is quite complicated; hence, it is difficult to explain the above experimental results. However, it can be expected that equilibrium affects catalytic performance at 40 h. This can be also proven by the RWGSR using $\mathrm{Ru}_{3}(\mathrm{CO})_{12}$. Similar TONs were obtained for the RWGSR using $\left[\mathrm{RuCl}_{2}(\mathrm{CO})_{3}\right]_{2}$ and $\mathrm{Ru}_{3}(\mathrm{CO})_{12}$ at $40 \mathrm{~h}$, although the TON of the RWGSR using $\mathrm{Ru}_{3}(\mathrm{CO})_{12}$ is only $c a$. two-thirds of that using $\left[\mathrm{RuCl}_{2}(\mathrm{CO})_{3}\right]_{2}$ at $10 \mathrm{~h}$. The catalytic activity of $\mathrm{RuCl}_{3}$ for the RWGSR was induced by heat treatment under CO atmosphere, resulting in a comparable TON to that of the other catalysts. This may be due to the generation of $\left[\mathrm{RuCl}_{2}(\mathrm{CO})_{3}\right]_{2}$ by heating $\mathrm{RuCl}_{3}$ under $\mathrm{CO}$ atmosphere.[53] For subsequent analyses, the catalyst and reaction time were fixed to $\left[\mathrm{RuCl}_{2}(\mathrm{CO})_{3}\right]_{2}$ and $10 \mathrm{~h}$, respectively.

\subsection{Optimization of IL content}

To determine the optimum amount of IL in the SILP catalyst, SILP catalysts were prepared from $10.0 \mathrm{~g}$ of Wakosil C-200 and $60 \mathrm{mg}$ of $\left[\mathrm{RuCl}_{2}(\mathrm{CO})_{3}\right]_{2}$ with various amounts of $\left[\mathrm{C}_{4} \mathrm{mim}\right] \mathrm{Cl}(0-$ 
$8.0 \mathrm{~g})$, and abbreviated as SILP-Cl $(\mathrm{X})$, where $\mathrm{X}$ indicates the amount of [ $\left.\mathrm{C}_{4} \mathrm{mim}\right] \mathrm{Cl}$ employed in grams. All SILP catalysts were obtained as smooth and dry powders, except for SILP-Cl (8.0), which appeared slightly damp. The RWGSR was then carried out using these SILP catalysts. The TONs of each reaction are listed in Table 1 and plotted against the $\mathrm{X}$ values in Figure 3 . When $\left[\mathrm{C}_{4} \mathrm{mim}\right] \mathrm{Cl}$ was not employed (SILP-Cl (0)), no catalytic activity was observed, indicating that $\left[\mathrm{RuCl}_{2}(\mathrm{CO})_{3}\right]_{2}$ should be dissolved in IL to act as a catalyst. With increasing $\left[\mathrm{C}_{4} \mathrm{mim}\right] \mathrm{Cl}$, the catalytic activity significantly increased, and a maximum TON was achieved with SILP-Cl (1.6) (TON $=241)$. However, above $X=1.6$, the catalytic activity decreased again and the TON was only 70 for SILP-Cl (8.0).

Results for the Brunauer-Emmett-Teller (BET) surface area analysis of SILP-Cl (X) are listed in Table 1 . The specific surface area $\left(S_{\mathrm{BET}}\right)$ and pore volume $\left(V_{\mathrm{BJH}}\right)$ of Wakosil C-200 were $555 \mathrm{~m}^{2} \mathrm{~g}^{-1}$ and $0.928 \mathrm{~cm}^{3} \mathrm{~g}^{-1}$ respectively, and both characteristics decreased with an increasing amount of $\left[\mathrm{C}_{4} \mathrm{mim}\right] \mathrm{Cl}$, indicating that $\left[\mathrm{C}_{4} \mathrm{mim}\right] \mathrm{Cl}$ was impregnated in the pore of Wakosil C-200. The theoretical pore volume $\left(V_{\mathrm{th}}\right)$ was calculated by subtracting the mounted volume of $\left[\mathrm{C}_{4} \mathrm{mim}\right] \mathrm{Cl}$ from the initial pore volume of Wakosil C-200 and plotted with $V_{\mathrm{BJH}}$ in Figure 4. As shown in Figure $4, V_{\mathrm{BJH}}$ is plotted beneath the line of $V_{\mathrm{th}}$, indicating that $\left[\mathrm{C}_{4} \mathrm{mim}\right] \mathrm{Cl}$ introduced in the pore of Wakosil C-200 deposited on the bottleneck of the pore, resulting in a sudden decrease in $V_{\mathrm{BJH}}$. In the ESI-MS spectrum measured for SILP-Cl $(0.04)$ of $\left[\mathrm{C}_{4} \mathrm{mim}\right] \mathrm{Cl},\left[\mathrm{RuCl}_{3}(\mathrm{CO})_{3}\right]^{-}(\mathrm{m} / \mathrm{z}=$ 292.8) is observed as the main peak (Figure 5 (a)), indicating that $\left[\mathrm{RuCl}_{2}(\mathrm{CO})_{3}\right]_{2}$ is converted to $\left[\mathrm{RuCl}_{3}(\mathrm{CO})_{3}\right]^{-}$during the preparation of the SILP catalyst. DRIFTS spectra of the SILP catalysts are 
shown in Figure 5 (b). The two peaks observed between $2050 \mathrm{~cm}^{-1}$ and $2150 \mathrm{~cm}^{-1}$ can be assigned to asymmetric and symmetric $\mathrm{C} \equiv \mathrm{O}$ vibrations of $\left[\mathrm{RuCl}_{3}(\mathrm{CO})_{3}\right]^{-}$. When the catalyst was mounted alone on Wakosil C-200 (SILP-Cl (0)), peaks corresponding to the C $\equiv \mathrm{O}$ vibration appear at 2144 $\mathrm{cm}^{-1}$ and $2078 \mathrm{~cm}^{-1}$. With increasing $\left[\mathrm{C}_{4} \mathrm{mim}\right] \mathrm{Cl}$, these peaks shift to lower wavenumber and appear at $2123 \mathrm{~cm}^{-1}$ and $2050 \mathrm{~cm}^{-1}$ for SILP-Cl (1.6). However, the peak shift saturated at quantities of $\left[\mathrm{C}_{4} \mathrm{mim}\right] \mathrm{Cl}$ above $1.6 \mathrm{~g}$. The fact that only two $\mathrm{C} \equiv \mathrm{O}$ vibration peaks were observed for all SILP catalysts, indicates that all of $\left[\mathrm{RuCl}_{2}(\mathrm{CO})_{3}\right]_{2}$ was converted to $\left[\mathrm{RuCl}_{3}(\mathrm{CO})_{3}\right]^{-}$, even in the case of SILP-Cl (0.04) where the molar ratio of $\left[\mathrm{C}_{4} \mathrm{mim}\right] \mathrm{Cl}$ to $\mathrm{Ru}$ atom in the catalyst is $c a$. 1 , and the solvation of $\left[\mathrm{RuCl}_{2}(\mathrm{CO})_{3}\right]_{2}$ by $\left[\mathrm{C}_{4} \mathrm{mim}\right] \mathrm{Cl}$ increases with increasing amounts of $\left[\mathrm{C}_{4} \mathrm{mim}\right] \mathrm{Cl}$ up to SILP-Cl (1.6).

From these results, we concluded that the effect of the amount of ILs is as follows: $\left[\mathrm{RuCl}_{3}(\mathrm{CO})_{3}\right]^{-}$can be generated from $\left[\mathrm{RuCl}_{2}(\mathrm{CO})_{3}\right]_{2}$ even when the amount of $\left[\mathrm{C}_{4} \mathrm{mim}\right] \mathrm{Cl}$ is only $40 \mathrm{mg}$ for $60 \mathrm{mg}$ of $\left[\mathrm{RuCl}_{2}(\mathrm{CO})_{3}\right]_{2}$, which corresponds to a IL/Ru molar ratio of $c a$. 1 . However, an extra amount of $\left[\mathrm{C}_{4} \mathrm{mim}\right] \mathrm{Cl}$ is required to induce catalytic activity of $\left[\mathrm{RuCl}_{3}(\mathrm{CO})_{3}\right]^{-}$, since $\left[\mathrm{RuCl}_{3}(\mathrm{CO})_{3}\right]^{-}$should be dissolved. Thus, the catalytic activity increases with an increasing amount of $\left[\mathrm{C}_{4} \mathrm{mim}\right] \mathrm{Cl}$. On the other hand, when the amount of $\left[\mathrm{C}_{4} \mathrm{mim}\right] \mathrm{Cl}$ is larger than $1.6 \mathrm{~g}$, the pores of Wakosil C-200 are excessively filled with it and the catalytic activity decreases, since the reactant gas must diffuse through a long distance in the IL phase to meet the catalyst molecule; this situation is disadvantageous from the point of view of mass transport. Based on these results, SILP-Cl (1.6) seems to have the optimum composition. Of course, if we change the amount of catalyst, the 
optimum amount of $\left[\mathrm{C}_{4} \mathrm{mim}\right] \mathrm{Cl}$ may change. However, for all subsequent analyses, the RWGSR was performed using the SILP-Cl (1.6) catalyst system.

Although the effects of the amount of IL on the reaction rate shown in Figure 3 appear to be in good agreement with the diffusion-reaction model[54, 55], the decrease in TON under higher liquid lording conditions seems to be rather small; only about $1 / 3$ of decrease in CO yield was observed when SILP-Cl (1.6) was replaced with SILP-Cl (8.0). This result suggests that the mass transport rate of gases in IL layer is almost comparable to the reaction rate of RWGSR even when whole pore of SILP is fully filled with IL.

\subsection{Catalytic cycle of RWGSR using SILP}

For the RWGSR using our SILP catalyst, the active Ru species was investigated by ESI-MS. Figure 6 shows the catalytic cycle which was proposed by Tominaga for the RWGSR under conventional homogeneous conditions using $\left[\mathrm{RuCl}_{2}(\mathrm{CO})_{3}\right]_{2}$, bis(triphenylphosphine)iminium chloride ([PPN]Cl), and $N$-methyl-2-pyrrolidone (NMP) as the catalyst, chloride, and reaction solvent, respectively[34]. In his report, the reaction solution was heat-treated under $\mathrm{N}_{2}, \mathrm{H}_{2}$, and $\mathrm{H}_{2} / \mathrm{CO}_{2}$ atmospheres, and catalytically active Ru species were detected by ESI-MS measurement. In this study, a similar approach was adopted for the RWGSR using a SILP catalyst. Heat treatment of SILP-Cl (1.6) was performed at $170{ }^{\circ} \mathrm{C}$ under $\mathrm{N}_{2}, \mathrm{H}_{2}$, and $\mathrm{H}_{2} / \mathrm{CO}_{2}$ atmospheres for $10 \mathrm{~h}$. Subsequently, Ru species were eluted by methanol and negative mode ESI-MS was performed. The results are shown in Figure 7. Before heat treatment, the main peak was observed at $\mathrm{m} / \mathrm{z}=292.8$ 
and assigned to $\left[\mathrm{RuCl}_{3}(\mathrm{CO})_{3}\right]^{-}$, as stated in the previous section. After heat treatment under $\mathrm{N}_{2}$, the main peak was shifted to $\mathrm{m} / \mathrm{z}=264.9$. This peak can be assigned to $\left[\mathrm{RuCl}_{3}(\mathrm{CO})_{2}\right]^{-}$, which is generated by the elimination of $\mathrm{CO}$ from $\left[\mathrm{RuCl}_{3}(\mathrm{CO})_{3}\right]^{-}$. After heat treatment under $\mathrm{H}_{2}$, the main peak appears at $\mathrm{m} / \mathrm{z}=231.1$ with other peaks $(\mathrm{m} / \mathrm{z}=292.8$ and 264.9) having considerable intensity. This main peak can be assigned to $\left[\mathrm{RuHCl}_{2}(\mathrm{CO})_{3}\right]^{-}$, which is generated by $\mathrm{H}_{2}$ addition to $\left[\mathrm{RuCl}_{3}(\mathrm{CO})_{2}\right]^{-}$, following the elimination of $\mathrm{HCl}$. These results are similar to those reported by Tominaga for the RWGSR under conventional homogeneous conditions.[34] Therefore, we concluded that the RWGSR using SILP-Cl (1.6) proceeds according to the same catalytic cycle as that under conventional homogeneous conditions using NMP (Figure 6). However, a difference between the two systems was also found. When heat treatment was performed under $\mathrm{H}_{2} / \mathrm{CO}_{2}$ mixed gas, which demonstrates RWGSR conditions, the main peak was observed at $\mathrm{m} / \mathrm{z}=264.9$ and 292.8 for SILP-Cl (1.6) and the conventional homogeneous system reported by Tominaga, respectively. This indicates that the rate-determining step is different between the two systems, that is, the rate-determining step in the SILP system is $\mathrm{H}_{2}$ addition to $\left[\mathrm{RuCl}_{3}(\mathrm{CO})_{2}\right]^{-}$following elimination of $\mathrm{HCl}$, while that in the homogeneous system is the elimination of $\mathrm{CO}$ from $\left[\mathrm{RuCl}_{3}(\mathrm{CO})_{3}\right]^{-}$. Additionally, other Ru species, $\left[\mathrm{RuCl}_{3}(\mathrm{CO})_{3}\right]^{-}$and $\left[\mathrm{RuHCl}_{2}(\mathrm{CO})_{2}\right]^{-}$were also detected in the case of the SILP system, indicating that there is no absolute difference in the activation energy of each step in the catalytic cycle for the RWGSR using SILP-Cl (1.6). On the other hand, only $\left[\mathrm{RuCl}_{3}(\mathrm{CO})_{3}\right]^{-}$was observed for the homogeneous system, and thus $\mathrm{CO}$ elimination from $\left[\mathrm{RuCl}_{3}(\mathrm{CO})_{3}\right]^{-}$must have a higher activation energy compared to other steps in the catalytic cycle. 
DRIFTS measurement was also performed for these SILP samples and results are shown in Figure

S1. Even for SILP system, similar relationship between ESI-MS spectra and DRIFTS spectra to that reported by Tominaga for homogeneous system[34] was observed. The difference between the SILP and homogeneous systems is further discussed in the following section.

\subsection{Comparison between SILP and homogeneous system}

The RWGSR was performed under homogeneous conditions and the results are listed in Table 2. When $5.0 \mathrm{mg}$ of $\left[\mathrm{RuCl}_{2}(\mathrm{CO})_{3}\right]_{2}$ and $160 \mathrm{mg}$ of $\left[\mathrm{C}_{4} \mathrm{mim}\right] \mathrm{Cl}$, which are similar amounts to those in $1.0 \mathrm{~g}$ of SILP-Cl (1.6), were employed (Table 2, entry 1), the TON was 125, which is approximately half of that for SILP-Cl (1.6). When $800 \mathrm{mg}$ of $\left[\mathrm{C}_{4} \mathrm{mim}\right] \mathrm{Cl}$ was employed, the TON decreased to 44 (Table 2, entry 2). This result indicates that mass transport properties affect the reaction rate.

Further investigation of the homogeneous system was performed using ESI-MS. The ESI-MS spectrum measured for the homogeneous system after the RWGSR (listed in Table 2 as entry 1) is shown in Figure 8 with the data for SILP-Cl (1.6). For the homogeneous system, $\left[\mathrm{RuHCl}_{2}(\mathrm{CO})_{2}\right]^{-}(\mathrm{m} / \mathrm{z}=231.1)$ was detected as the main peak. (Figure 8 (a)) This result is different from that of SILP-Cl (1.6) (Figure 8 (b)), although the composition of the reaction solution (catalyst/IL) and the temperature are the same for both systems, indicating that the activation energy of the catalytic cycle changes by immobilizing the reaction solution on the silica gel surface. Since the addition of $\mathrm{CO}_{2}$ to the metal center is generally dominated by the partial pressure of $\mathrm{CO}_{2}$, 
protonation of $\left[\mathrm{RuHCl}_{2}(\mathrm{CO})_{2}\left(\mathrm{CO}_{2}\right)\right]^{-}$must be the rate-determining step for entry 1 rather than $\mathrm{CO}_{2}$ addition to $\left[\mathrm{RuHCl}_{2}(\mathrm{CO})_{2}\right]^{-}$. Furthermore, it can be expected that the silica gel surface facilitates protonation of $\left[\mathrm{RuHCl}_{2}(\mathrm{CO})_{2}\left(\mathrm{CO}_{2}\right)\right]^{-}$. Wassersheid and his coworkers reported that due to the more basic property of the surface, an alumina support is more suitable for the water-gas shift reaction than a silica support. We also prepared a SILP catalyst using alumina and carried out the RWGSR. In our case (the RWGSR), however, lower catalytic activity (TON=114) was obtained compared to the SILP catalyst based on silica gel. This result is consistent with our hypothesis about the effect of the silica surface, since the more acidic nature of the silica surface $(\mathrm{pH}$ at point of zero charge (PZC) is ca. 2) than alumina ( $\mathrm{pH}$ at PZC is ca. 9) is advantageous for protonation. The effect of the support on catalytic activity should be further investigated.

Thus, the enhancement of catalytic activity in the SILP system compared with the homogeneous system is realized by a greater mass transport rate derived from the large surface area of the porous support, as well as the effect of the surface of the silica gel support, which reduces the activation energy of the process in the catalytic cycle.

\subsection{Cycle performance}

Cycle performance was confirmed for SILP-Cl (1.6) by recycling the catalyst as follows. After the reaction, the employed SILP-Cl (1.6) was vacuumed at r.t. in an autoclave for 30 min to remove water evolved during the previous cycle. Then, reactant gases were introduced and the RWGSR was performed again. Figure 9 shows the results of the cycle test. In the first cycle, the 
TON was 241, as stated in the previous section, and the catalytic activity gradually decreased with an increasing number of cycles. However, ca. $60 \%$ of the TON was still maintained after 20 cycles, compared with the TON of the first cycle. We conclude that a fraction of the water evolved during the RWGSR still remained in the $\left[\mathrm{C}_{4} \mathrm{mim}\right] \mathrm{Cl}$ layer due to the strong hydrophilicity of $\left[\mathrm{C}_{4} \mathrm{mim}\right] \mathrm{Cl}$, resulting in gradual degradation of catalytic activity. During 20 cycles, the total TON reached 3600.

\section{Conclusions}

In this study, the RWGSR using a SILP catalyst consisting of Ru catalyst, IL, and a porous silica gel support, was investigated. The catalytic activity of the SILP catalyst strongly depends on the amount of $\left[\mathrm{C}_{4} \mathrm{mim}\right] \mathrm{Cl}$ in the pores of the silica gel, and it was demonstrated that SILP-Cl (1.6) shows the best performance (TON=241). Additionally, 20 cycles of the RWGSR using SILP-Cl (1.6) were accomplished. ESI-MS measurement of the SILP catalyst which was heat-treated under various atmospheres reveals that the RWGSR using the SILP catalyst proceeds according to same catalytic cycle as that under the homogeneous system NMP/[PPN]Cl. However, it also reveals that the rate-determining steps of the two systems are different. Further investigation of the homogeneous system reveals the effect of the silica support on the activation energy of the process in the catalytic cycle. Thus, we concluded that not only the high mass transport rate, but also the effect of the porous silica gel support, enhance the catalytic activity of the SILP system compared to a conventional homogeneous system. These results encourage us to further investigate SILP systems. 


\section{Acknowledgement}

We greatly appreciate Dr. Marco Haumann, group leader of SILP technology in Friedrich-Alexander-Universität Erlangen-Nürnberg (FAU), for kind discussion with us.

\section{Refferences}

[1] M.A. Pena, J.P. Gomez, J.L.G. Fierro, New catalytic routes for syngas and hydrogen production, Appl. Catal., A 144 (1996) 7-57.

[2] S.S. Bharadwaj, L.D. Schmidt, Catalytic partial oxidation of natural-gas to syngas, Fuel Process. Technol. 42 (1995) 109-127.

[3] I. Wender, Reactions of synthesis gas, Fuel Process. Technol. 48 (1996) 189-297.

[4] J.J. Spivey, A. Egbebi, Heterogeneous catalytic synthesis of ethanol from biomass-derived syngas, Chem. Soc. Rev. 36 (2007) 1514-1528.

[5] V. Subramani, S.K. Gangwal, A review of recent literature to search for an efficient catalytic process for the conversion of syngas to ethanol, Energy \& Fuels 22 (2008) 814-839.

[6] D.J. Wilhelm, D.R. Simbeck, A.D. Karp, R.L. Dickenson, Syngas production for gas-to-liquids applications: technologies, issues and outlook, Fuel Process. Technol. 71 (2001) 139-148.

[7] D.F. Jin, B. Zhu, Z.Y. Hou, J.H. Fel, H. Lou, X.M. Zheng, Dimethyl ether synthesis via methanol and syngas over rare earth metals modified zeolite Y and dual Cu-Mn-Zn catalysts, Fuel 86 (2007) 2707-2713.

[8] C. Yang, Z.Y. Ma, N. Zhao, W. Wei, T.D. Hu, Y.H. Sun, Methanol synthesis from $\mathrm{CO}_{2}$-rich syngas over a ZrO doped CuZnO catalyst, Catal. Today 115 (2006) 222-227.

[9] R.Q. Yang, Y.L. Fu, Y. Zhang, N. Tsubaki, In situ DRIFT study of low-temperature methanol synthesis mechanism on $\mathrm{Cu} / \mathrm{ZnO}$ catalysts from $\mathrm{CO}_{2}$-containing syngas using ethanol promoter, J. Catal. 228 (2004) 23-35.

[10] B.Q. Xu, W.M.H. Sachtler, Rh/NaY: A selective catalyst for direct synthesis of acetic acid from syngas, J. Catal. 180 (1998) 194-206.

[11] A. Goguet, F.C. Meunier, D. Tibiletti, J.P. Breen, R. Burch, Spectrokinetic investigation of reverse water-gas-shift reaction intermediates over a Pt/CeO2 catalyst, J. Phys. Chem. B 108 (2004) 20240-20246.

[12] A. Goguet, F. Meunier, J.P. Breen, R. Burch, M.I. Petch, A.F. Ghenciu, Study of the origin of the deactivation of a $\mathrm{Pt} / \mathrm{CeO}_{2}$ catalyst during reverse water gas shift (RWGS) reaction, J. Catal. 226 (2004) 382-392.

[13] D. Tibiletti, A. Goguet, F.C. Meunier, J.P. Breen, R. Burch, On the importance of steady-state isotopic techniques for the investigation of the mechanism of the reverse water-gas-shift reaction, Chem. Commun. (2004) 1636-1637.

[14] S. Ando, Y. Koyama, S. Miyata, S. Sato, S. Kanehashi, K. Nagai, Synthesis and characterization of ABA-type triblock copolymers derived from polyimide and poly(2-methyl-2-adamantyl methacrylate), Polym. Int. 63 (2014) 1634-1642. 
[15] D. Baudouin, U. Rodemerck, F. Krumeich, A. de Mallmann, K.C. Szeto, H. Menard, L. Veyre, J.P. Candy, P.B. Webb, C. Thieuleux, C. Coperet, Particle size effect in the low temperature reforming of methane by carbon dioxide on silica-supported Ni nanoparticles, J. Catal. 297 (2013) 27-34.

[16] F.V. Vazquez, P. Pfeifer, J. Lehtonen, P. Piermartini, P. Simell, V. Alopaeus, Catalyst screening and kinetic modeling for CO production by high pressure and temperature reverse water gas shift for Fischer-Tropsch applications, Ind. Eng. Chem. Res. 56 (2017) 13263-13273.

[17] M.T. Rodrigues, P.C. Zonetti, O.C. Alves, E.F. Sousa-Aguiar, L.E.P. Borges, L.G. Appel, RWGS reaction employing Ni/Mg(Al,Ni)O - The role of the O vacancies, Appl. Catal., A 543 (2017) 98-103.

[18] F. Bustamante, R.M. Enick, A.V. Cugini, R.P. Killmeyer, B.H. Howard, K.S. Rothenberger, M.V. Ciocco, B.D. Morreale, High-temperature kinetics of the homogeneous reverse water-gas shift reaction, AlChE J. 50 (2004) 1028-1041.

[19] C.S. Chen, W.H. Cheng, S.S. Lin, Study of iron-promoted $\mathrm{Cu} / \mathrm{SiO}_{2}$ catalyst on high temperature reverse water gas shift reaction, Appl. Catal., A 257 (2004) 97-106.

[20] C.S. Chen, W.H. Cheng, S.S. Lin, Study of reverse water gas shift reaction by TPD, TPR and $\mathrm{CO}_{2}$ hydrogenation over potassium-promoted $\mathrm{Cu} / \mathrm{SiO}_{2}$ catalyst, Appl. Catal., A 238 (2003) 55-67.

[21] M.J.L. Gines, A.J. Marchi, C.R. Apesteguia, Kinetic study of the reverse water-gas shift reaction over $\mathrm{CuO} / \mathrm{ZnO} / \mathrm{Al}_{2} \mathrm{O}_{3}$ catalysts, Appl. Catal., A 154 (1997) 155-171.

[22] D. Waller, D. Stirling, F.S. Stone, M.S. Spencer, Copper-zin oxide catalysts - activity in relation to precursor structure and morphology, Faraday Discuss. 87 (1989) 107-120.

[23] C.S. Chen, W.H. Cheng, S.S. Lin, Mechanism of CO formation in reverse water-gas shift reaction over $\mathrm{Cu} / \mathrm{Al}_{2} \mathrm{O}_{3}$ catalyst, Catal. Lett. 68 (2000) 45-48.

[24] H.T. Xu, Y.S. Li, X.K. Luo, Z.L. Xu, J.P. Ge, Monodispersed gold nanoparticles supported on a zirconium-based porous metal-organic framework and their high catalytic ability for the reverse water-gas shift reaction, Chem. Commun. 53 (2017) 7953-7956.

[25] R. Carrasquillo-Flores, I. Ro, M.D. Kumbhalkar, S. Burt, C.A. Carrero, A.C. Alba-Rubio, J.T. Miller, I. Hermans, G.W. Huber, J.A. Dumesic, Reverse water-gas shift on interfacial sites formed by deposition of oxidized molybdenum moieties onto gold nanoparticles, J. Am. Chem. Soc. 137 (2015) 10317-10325.

[26] M. Manzoli, A. Chiorino, F. Vindigni, F. Boccuzzi, Hydrogen interaction with gold nanoparticles and clusters supported on different oxides: A FTIR study, Catal. Today 181 (2012) 62-67.

[27] Z.S. Fishman, Y.L. He, K.R. Yang, A.W. Lounsbury, J.Q. Zhu, T.M. Tran, J.B. Zimmerman, V.S. Batista, L.D. Pfefferle, Hard templating ultrathin polycrystalline hematite nanosheets: effect of nano-dimension on $\mathrm{CO}_{2}$ to $\mathrm{CO}$ conversion via the reverse water-gas shift reaction, Nanoscale 9 (2017) 12984-12995.

[28] G.W. Roberts, P. Chin, X.L. Sun, J.J. Spivey, Preferential oxidation of carbon monoxide with Pt/Fe monolithic catalysts: interactions between external transport and the reverse water-gas-shift reaction, Appl. Catal., B 46 (2003) 601-611.

[29] R. Merkache, I. Fechete, M. Maamache, M. Bernard, P. Turek, K. Al-Dalama, F. Garin, 3D ordered mesoporous Fe-KIT-6 catalysts for methylcyclopentane (MCP) conversion and carbon dioxide $\left(\mathrm{CO}_{2}\right)$ hydrogenation for energy and environmental applications, Appl. Catal., A 504 (2015) 672-681.

[30] R.C. Baliban, J.A. Elia, C.A. Floudas, Optimization framework for the simultaneous process synthesis, heat and 
power integration of a thermochemical hybrid biomass, coal, and natural gas facility, Comput. Chem. Eng. 35 (2011) 1647-1690.

[31] G. Pekridis, K. Kalimeri, N. Kaklidis, E. Vakouftsi, E.F. Iliopoulou, C. Athanasiou, G.E. Marnellos, Study of the reverse water gas shift (RWGS) reaction over Pt in a solid oxide fuel cell (SOFC) operating under open and closed-circuit conditions, Catal. Today 127 (2007) 337-346.

[32] T. Yoshida, D.L. Thorn, T. Okano, J.A. Ibers, S. Otsuka, Hydration and reduction of carbon-dioxide by rhodium hydride compounds - preparation and reactions of rhodium bicarbonate and formate complexes, and the molecular-structure of $\mathrm{RhH}_{2}\left(\mathrm{O}_{2} \mathrm{COH}\right)\left(\mathrm{P}(\mathrm{i}-\mathrm{PR})_{3}\right)_{2}$, J. Am. Chem. Soc. 101 (1979) 4212-4221.

[33] K.-I. Tominaga, Y. Sasaki, T. Watanabe, M. Saito, Ethylene oxide-mediated reverse water-gas shift reaction catalyzed by ruthenium complexes, Energy 22 (1997) 169-176.

[34] K. Tsuchiya, J.D. Huang, K. Tominaga, Reverse Water-Gas Shift Reaction Catalyzed by Mononuclear Ru Complexes, ACS Catal. 3 (2013) 2865-2868.

[35] W. Li, S. Guo, L. Guo, Theoretical Investigation of Reverse Water Gas Shift Reaction Catalyzed by Ruthenium Halogen Carbonyl Complexes, Catalysis Surveys from Asia 21 (2017) 185-197.

[36] R. Franke, D. Selent, A. Börner, Applied Hydroformylation, Chem. Rev. 112 (2012) 5675-5732.

[37] C. Bianchini, D.G. Burnaby, J. Evans, P. Frediani, A. Meli, W. Oberhauser, R. Psaro, L. Sordelli, F. Vizza, Preparation, characterization, and performance of tripodal polyphosphine rhodium catalysts immobilized on silica via hydrogen bonding, J. Am. Chem. Soc. 121 (1999) 5961-5971.

[38] G.J.H. Buisman, P.C.J. Kamer, P. Vanleeuwen, Rhodium catalyzed asymetric hydroformylation with Chiral diphosphite ligands, Tetrahedron: Asymmetry 4 (1993) 1625-1634.

[39] T. Hanaoka, H. Arakawa, T. Matsuzaki, Y. Sugi, K. Kanno, Y. Abe, Ethylene hydroformylation and carbon monoxide hydrogenation over modified and unmodified silica supported rhodium catalysts, Catal. Today 58 (2000) 271-280.

[40] K. Tominaga, Y. Sasaki, Biphasic hydroformylation of 1-hexene with carbon dioxide catalyzed by ruthenium complex in ionic liquids, Chem. Lett. 33 (2004) 14-15.

[41] K. Tominaga, Y. Sasaki, Ruthenium-catalyzed one-pot hydroformylation of alkenes using carbon dioxide as a reactant, J. Mol. Catal. A: Chem. 220 (2004) 159-165.

[42] K. Tominaga, Y. Sasaki, Ruthenium complex-catalyzed hydroformylation of alkenes with carbon dioxide, Catal. Commun. 1 (2000) 1-3.

[43] A. Riisager, P. Wasserscheid, R. van Hal, R. Fehrmann, Continuous fixed-bed gas-phase hydroformylation using supported ionic liquid-phase (SILP) Rh catalysts, J. Catal. 219 (2003) 452-455.

[44] A. Riisager, K.M. Eriksen, P. Wasserscheid, R. Fehrmann, Propene and l-octene hydroformylation with silica-supported, ionic liquid-phase (SILP) Rh-phosphine catalysts in continuous fixed-bed mode, Catal. Lett. 90 (2003) 149-153.

[45] A. Riisager, R. Fehrmann, M. Haumann, B.S.K. Gorle, P. Wasserscheid, Stability and kinetic studies of supported ionic liquid phase catalysts for hydroformylation of propene, Ind. Eng. Chem. Res. 44 (2005) 9853-9859.

[46] M. Haumann, K. Dentler, J. Joni, A. Riisager, P. Wasserscheid, Continuous gas-phase hydroformylation of 1-butene using supported ionic liquid phase (SILP) catalysts, Adv. Synth. Catal. 349 (2007) 425-431.

[47] E. Oechsner, M.J. Schneider, C. Meyer, M. Haumann, P. Wasserscheid, Challenging the scope of continuous, 
gas-phase reactions with supported ionic liquid phase (SILP) catalysts-Asymmetric hydrogenation of methyl acetoacetate, Appl. Catal., A 399 (2011) 35-41.

[48] S. Werner, N. Szesni, A. Bittermann, M.J. Schneider, P. Harter, M. Haumann, P. Wasserscheid, Screening of Supported Ionic Liquid Phase (SILP) catalysts for the very low temperature water-gas-shift reaction, Appl. Catal., A 377 (2010) 70-75.

[49] S. Werner, N. Szesni, M. Kaiser, R.W. Fischer, M. Haumann, P. Wasserscheid, Ultra-Low-Temperature Water-Gas Shift Catalysis using Supported Ionic Liquid Phase (SILP) Materials, Chemcatchem 2 (2010) 1399-1402.

[50] M.J. Schneider, M. Lijewski, R. Woelfel, M. Haumann, P. Wasserscheid, Continuous Gas-Phase Hydroaminomethylation using Supported Ionic Liquid Phase Catalysts, Angew. Chem. Int. Ed. 52 (2013) 6996-6999.

[51] Proceeding of RWGSR can be evaluated by also amount of water generated during the reaction. Thus, in order to confirm whether hydgroscopic $\left[\mathrm{C}_{4} \mathrm{mim}\right] \mathrm{Cl}$ layer in SILP can retain generated water or not, we performed TG-DTA and Karl Fischer titration of SILP-Cl (1.6) after RWGSR. Unfortunately, much smaller amount of water comparing with expected amount was detected in both measurements. This may be due to reaction temperature (170 $\left.{ }^{\circ} \mathrm{C}\right)$ and overwhelming volume of space in autoclave comparing with the volume of [ $\left.\mathrm{C}_{4} \mathrm{mim}\right] \mathrm{Cl}$ in SILP-Cl (1.6).

[52] Tominaga reported that chloride based ionic liquid is preferable for RWGSR using $\left[\mathrm{RuCl}_{2}(\mathrm{CO})_{3}\right]_{2}$ among halogen anion based ionic liquids in ACS Catal., 3 (2013) 2865-2868. As a preliminary experiment, other than [ $\left.\mathrm{C}_{4} \mathrm{mim}\right] \mathrm{Cl}$, SILPs were prepared by using $\left[\mathrm{RuCl}_{2}(\mathrm{CO})_{3}\right]_{2}$ and some kind of ionic liquids such as 1-butyl-3-methylimidazolium bis(trifluoromethanesulfonyl)amide ([ $\left.\left.\mathrm{C}_{4} \mathrm{mim}\right][\mathrm{TFSA}]\right)$ 1-butyl-3-methylimidazolium trofluoromethanesulfonate

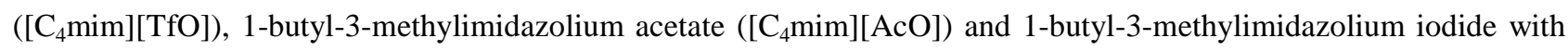
same composition of IL/catalyst/silica gel as SILP-Cl (1.6) and abbreviated as SILP-TFSA (1.6), SILP-TfO (1.6), SILP-AcO (1.6) and SILP-I (1.6), respectively. TON of RWGSR using these SILPs at $170{ }^{\circ} \mathrm{C}$ for $10 \mathrm{~h}$ under $\mathrm{P}_{\mathrm{CO} 2} / \mathrm{P}_{\mathrm{H} 2}=$ $2 \mathrm{MPa} / 6 \mathrm{MPa}$ were as follows; SILP-TFSA (1.6)=0, SILP-TfO (1.6)=0, SILP-AcO (1.6)=11 and SILP-I (1.6)=5. From these results, we decided to employ $\left[\mathrm{C}_{4} \mathrm{mim}\right] \mathrm{Cl}$ as ionic liquid for SILP in this study.

[53] M.I. Bruce, F.G.A. Stone, Chemistry of the metal carbonyls. Part XL. Carbonylation of ruthenium trichloride, J. Chem. Soc. A (1967) 1238-1241.

[54] R. Abed, R.G. Rinker, Diffusion-limited reaction in supported liquid-phase catalysis, J. Catal. 31 (1973) 119-126.

[55] R. Datta, R.G. Rinker, Supported liquid-phase catalysis: I. A theoretical model for transport and reaction, J. Catal. 95 (1985) 181-192. 
Table 1 BET surface area and pore volume of SILP-Cl (X) and results of RWGSR. ${ }^{\mathrm{a}} \mathrm{X}$ indicates employed amount of $\left[\mathrm{C}_{4} \mathrm{mim}\right] \mathrm{Cl}$ for preparation of SILP. (see manuscript)

\begin{tabular}{ccccc}
\hline entry & $\mathrm{X} / \mathrm{g}$ & $S_{\mathrm{BET}} / \mathrm{m}^{2} \mathrm{~g}^{-1}$ & $V_{\mathrm{BJH}} / \mathrm{cm}^{3} \mathrm{~g}^{-1}$ & $\mathrm{TON}$ \\
\hline 1 & 0 & 555.2 & 0.928 & 0 \\
2 & 0.04 & 559.7 & 0.817 & 12 \\
3 & 0.08 & 526.0 & 0.799 & 32 \\
4 & 0.2 & 505.4 & 0.762 & 88 \\
5 & 0.4 & 495.5 & 0.789 & 129 \\
6 & 0.8 & 416.0 & 0.660 & 202 \\
7 & 1.6 & 324.4 & 0.510 & 241 \\
8 & 3.2 & 159.8 & 0.300 & 169 \\
9 & 5.0 & 54.9 & 0.119 & 122 \\
10 & 8.0 & 0.085 & - & 70 \\
\hline
\end{tabular}

${ }^{\mathrm{a}}$ Reaction conditions: SILP catalyst (1.0 g), $\mathrm{H}_{2}(6 \mathrm{MPa}), \mathrm{CO}_{2}(2 \mathrm{MPa}), 170{ }^{\circ} \mathrm{C}, 10 \mathrm{~h}$. 
Table 2 Results of RWGSR under homogeneous conditions. ${ }^{\mathrm{a}}$

\begin{tabular}{cccc}
\hline entry & $W_{\text {cat }} / \mathrm{mg}$ & $W_{\mathrm{IL}} / \mathrm{mg}$ & TON \\
\hline 1 & 5.0 & 160 & 125 \\
2 & 5.0 & 800 & 44 \\
\hline
\end{tabular}

${ }^{\mathrm{a}}$ Reaction conditions: $\left[\mathrm{RuCl}_{2}(\mathrm{CO})_{3}\right]_{2}\left(W_{\text {cat }} \mathrm{mg}\right),\left[\mathrm{C}_{4} \mathrm{mim}\right] \mathrm{Cl}\left(W_{\mathrm{IL}} \mathrm{mg}\right), \mathrm{H}_{2}(6 \mathrm{MPa}), \mathrm{CO}_{2}(2 \mathrm{MPa})$, $170{ }^{\circ} \mathrm{C}, 10 \mathrm{~h}$. 


\section{Figure Caption}

Figure 1 Appearance of SILP catalyst and RWGSR using SILP catalyst.

Figure 2 Time dependence of TON for RWGSR using SILP catalyst based on various Ru catalysts. $^{\text {a }}$

${ }^{\mathrm{a}}$ Reaction conditions: SILP catalyst (1.0 g), $\mathrm{H}_{2}$ (6 MPa), $\mathrm{CO}_{2}(2 \mathrm{MPa}), 170{ }^{\circ} \mathrm{C}$.

Figure 3 Plot of TON for RWGSR using SILP-Cl (X) as a function of employed amount of $\left[\mathrm{C}_{4} \mathrm{mim}\right] \mathrm{Cl}{ }^{\mathrm{a}}$

${ }^{\mathrm{a}}$ Reaction conditions: SILP catalyst (1.0 g), $\mathrm{H}_{2}(6 \mathrm{MPa}), \mathrm{CO}_{2}(2 \mathrm{MPa}), 170{ }^{\circ} \mathrm{C}, 10 \mathrm{~h}$.

Figure 4 Plots of $V_{\mathrm{BJH}}$ and $V_{\text {th }}$ of SILP-C $(\mathrm{X})$ as a function of employed amount of [C $\left.\mathrm{C}_{4} \mathrm{mim}\right] \mathrm{Cl}$. Meaning of abbreviations were written in the manuscript.

Figure 5 ESI-MS spectrum measured for SILP-Cl (0.04) (a) and the results of DRIFTS measurement for SILP-Cl (X) (b).

Figure 6 Plausible catalytic cycle for RWGSR under homogeneous $\left[\mathrm{RuCl}_{2}(\mathrm{CO})_{3}\right]_{2} /[\mathrm{PPN}] \mathrm{Cl} / \mathrm{NMP}$ system reported in ref. 34. Roman numerals with parentheses indicate each process in catalytic cycle as follows; (i) transform to catalytically active mononuclear complex, (ii) elimination of CO, (iii) hydrogenation and elimination of $\mathrm{HCl}$, (iv) addition of $\mathrm{CO}_{2}(\mathrm{v})$ protonation and elimination of $\mathrm{H}_{2} \mathrm{O}$ and (vi) addition of $\mathrm{Cl}^{-}$.

Figure 7 ESI-MS spectra measured for SILP-Cl (1.6) treated under various atmosphere at $170{ }^{\circ} \mathrm{C}$ for 10 h. (a) Before treatment, (b) heat treatment under $\mathrm{N}_{2}$ (2 MPa), (c) heat treatment under $\mathrm{H}_{2}$ (2 $\mathrm{MPa}$ ), and (d) after reaction of $\mathrm{H}_{2}(6 \mathrm{MPa})$ and $\mathrm{CO}_{2}(2 \mathrm{MPa})$. 
Figure 8 Comparison of ESI-MS spectra between homogeneous system (a) and SILP-Cl(1.6) (b) after RWGSR. ${ }^{a}$

${ }^{\mathrm{a}}$ Reaction conditions: (a) $\left[\mathrm{RuCl}_{3}(\mathrm{CO})_{3}\right]_{2}(5.0 \mathrm{mg}),\left[\mathrm{C}_{4} \mathrm{mim}\right] \mathrm{Cl}$ (160 mg), $\mathrm{H}_{2}(6 \mathrm{MPa}), \mathrm{CO}_{2}(2 \mathrm{MPa})$, $170{ }^{\circ} \mathrm{C}, 10$ h. (b) SILP catalyst (1.0 g), $\mathrm{H}_{2}(6 \mathrm{MPa}), \mathrm{CO}_{2}(2 \mathrm{MPa}), 170{ }^{\circ} \mathrm{C}, 10 \mathrm{~h}$.

Figure 9 Cycle performance of SILP-Cl (1.6) on RWGSR.

Reaction conditions: SILP catalyst (1.0 g), $\mathrm{H}_{2}(6 \mathrm{MPa}), \mathrm{CO}_{2}(2 \mathrm{MPa}), 170{ }^{\circ} \mathrm{C}, 10 \mathrm{~h}$. The autoclave was vacuumed for 30 min before each cycle. 


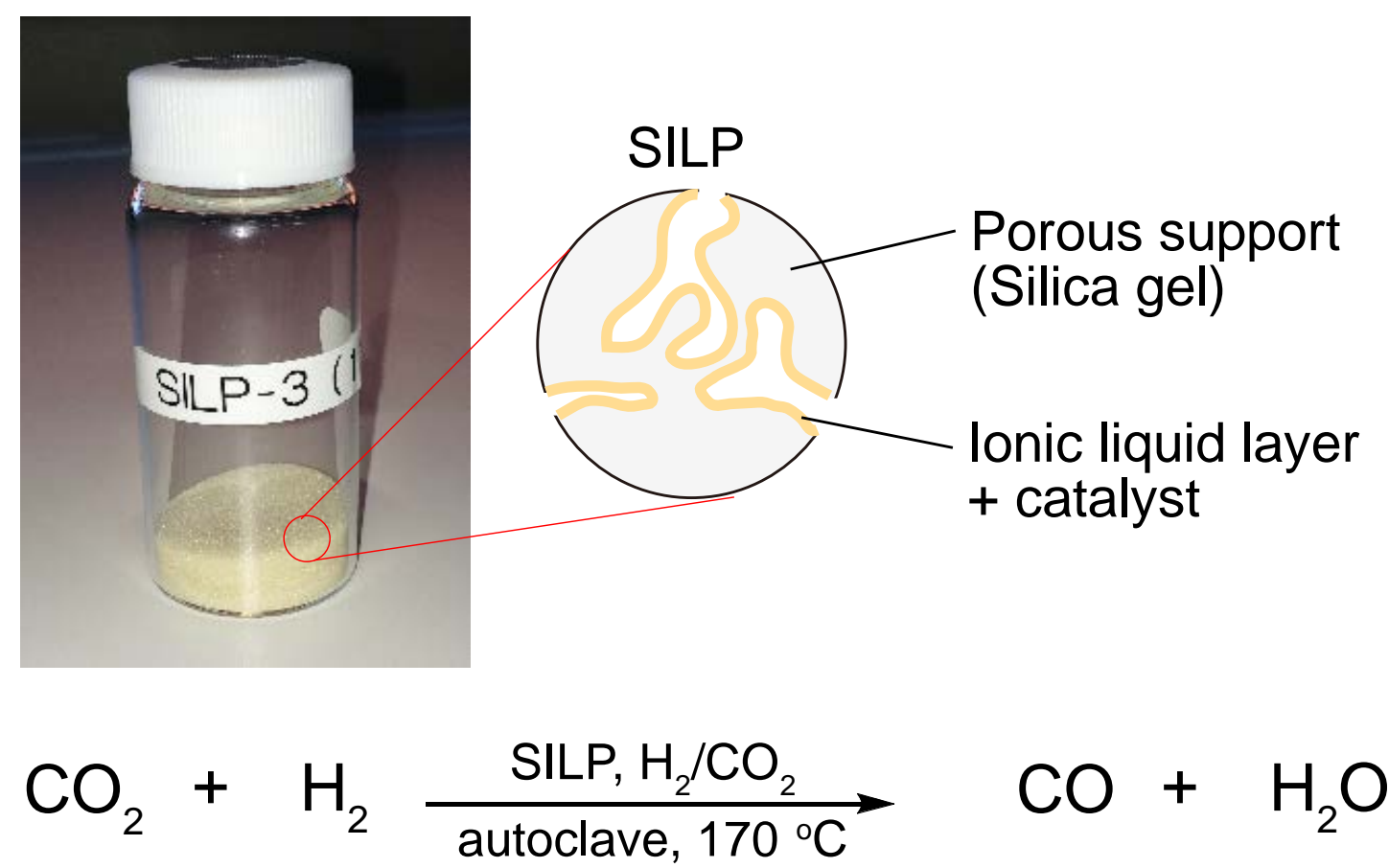

Figure 1 


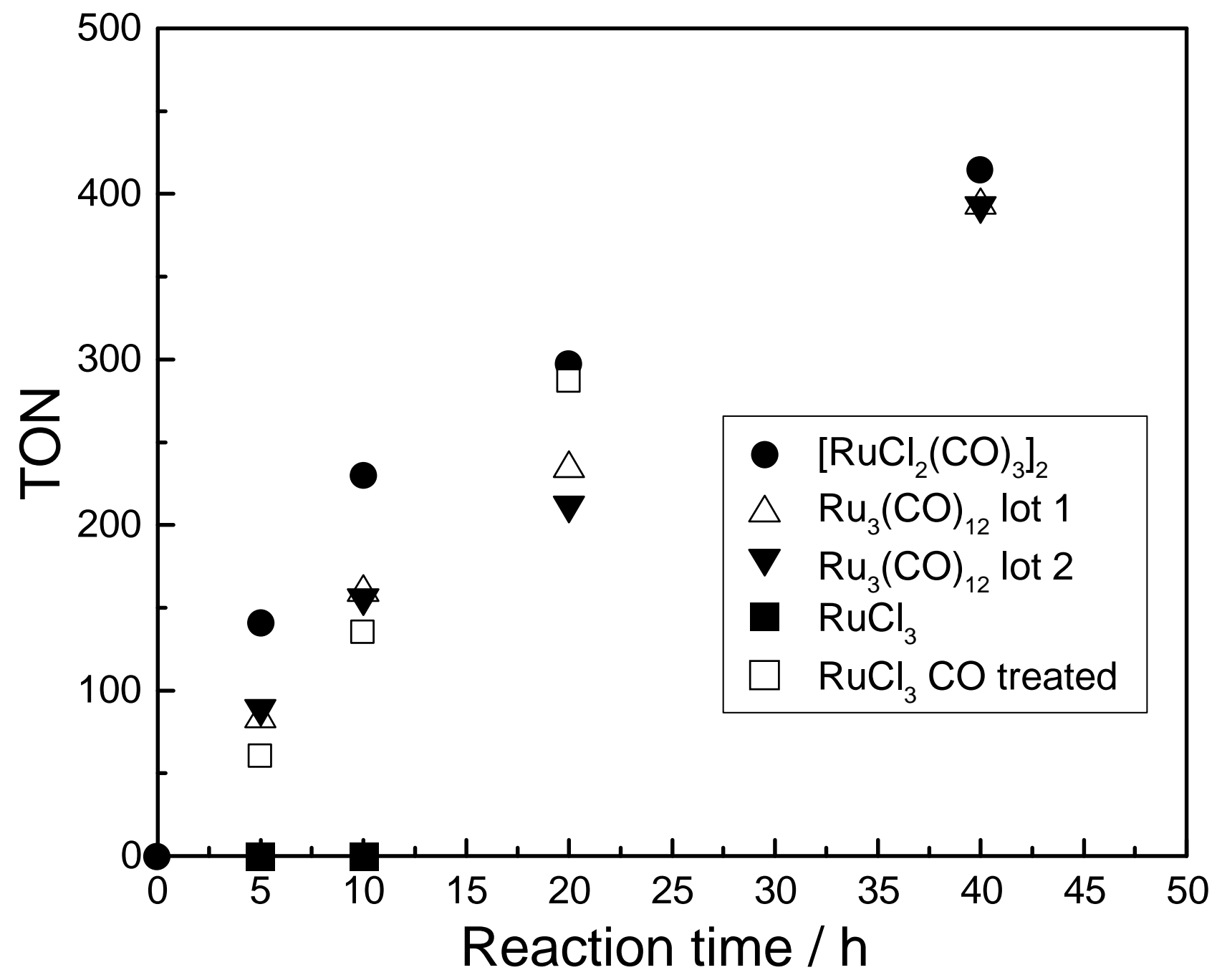

Figure 2 


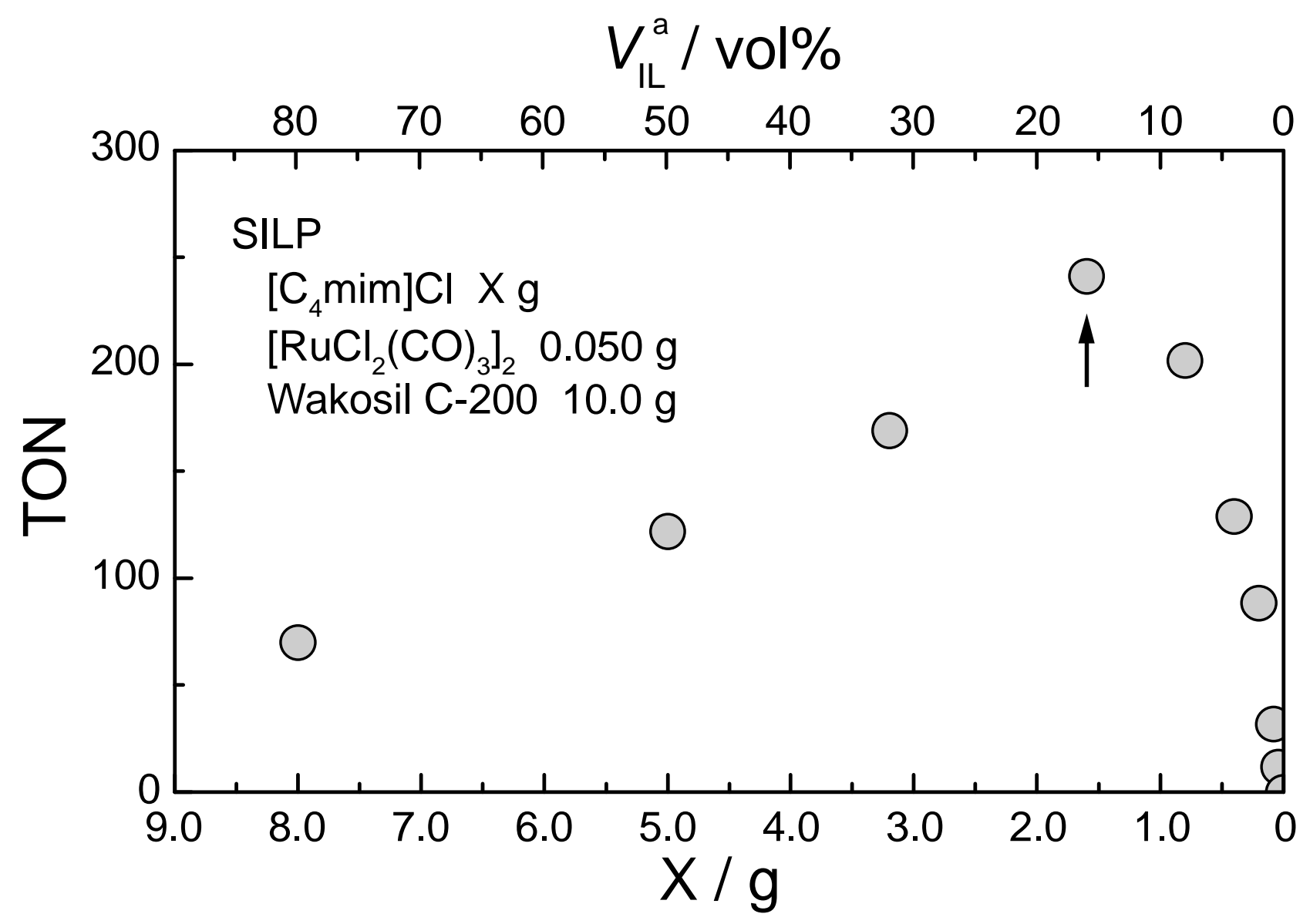

Figure 3 


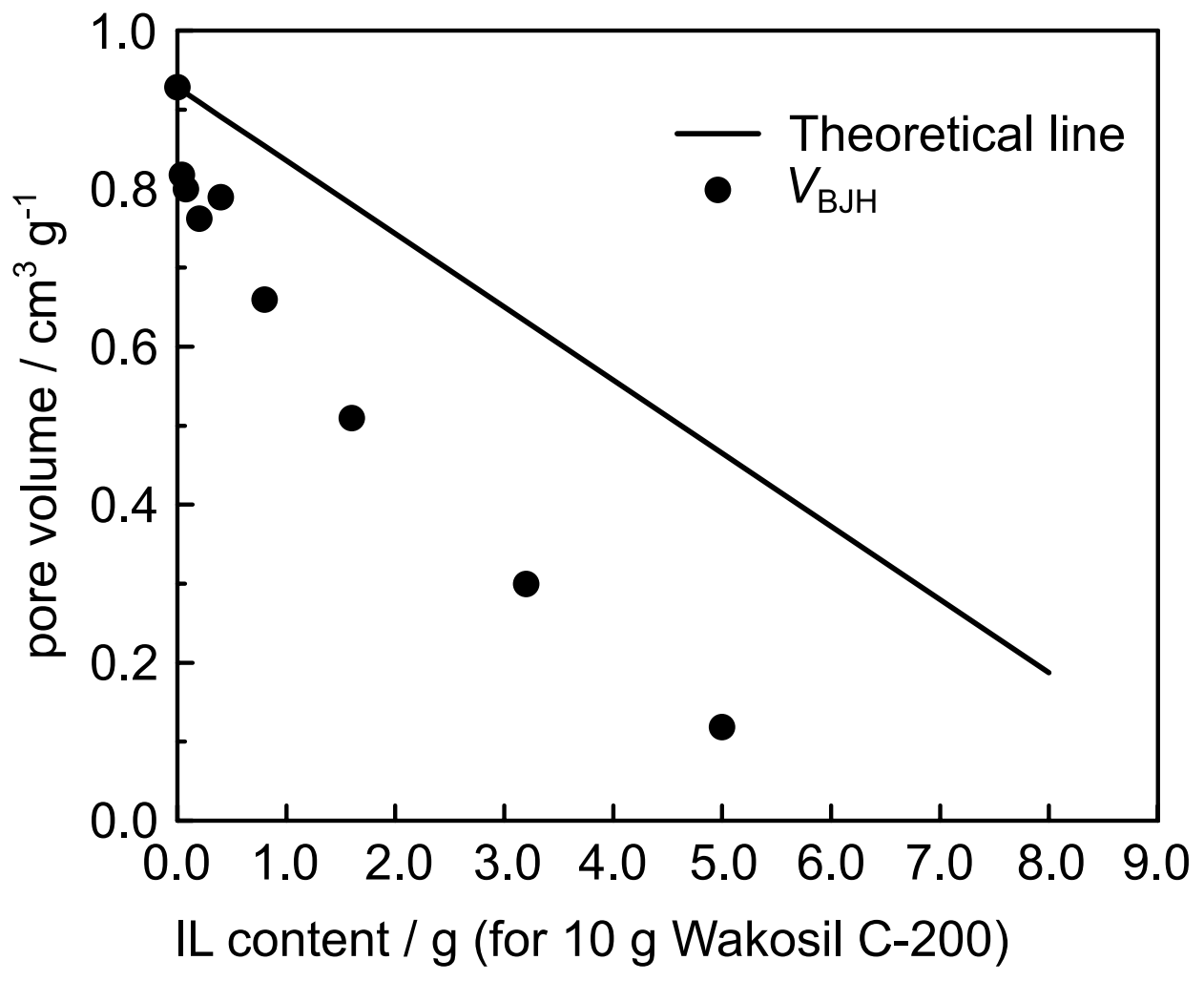

Figure 4 
(a)

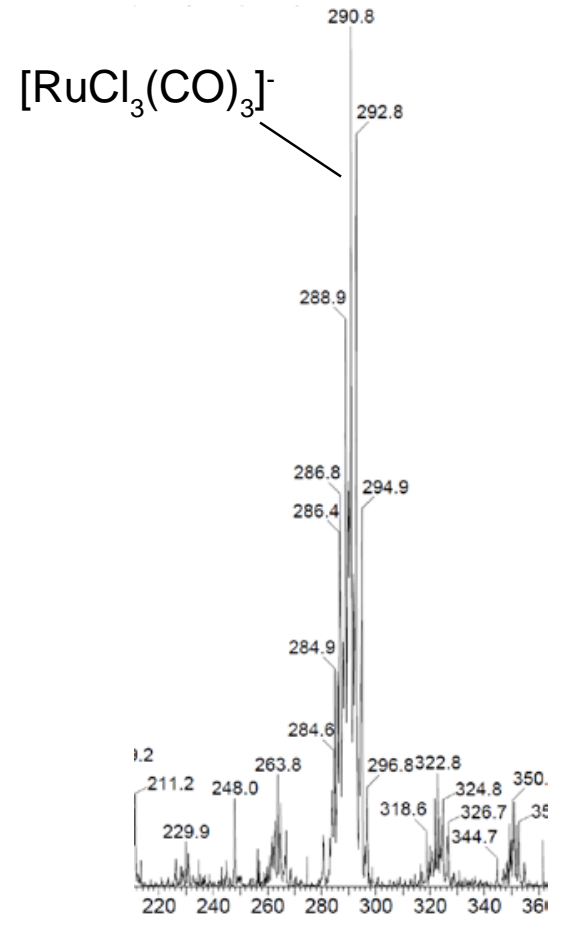

(b)

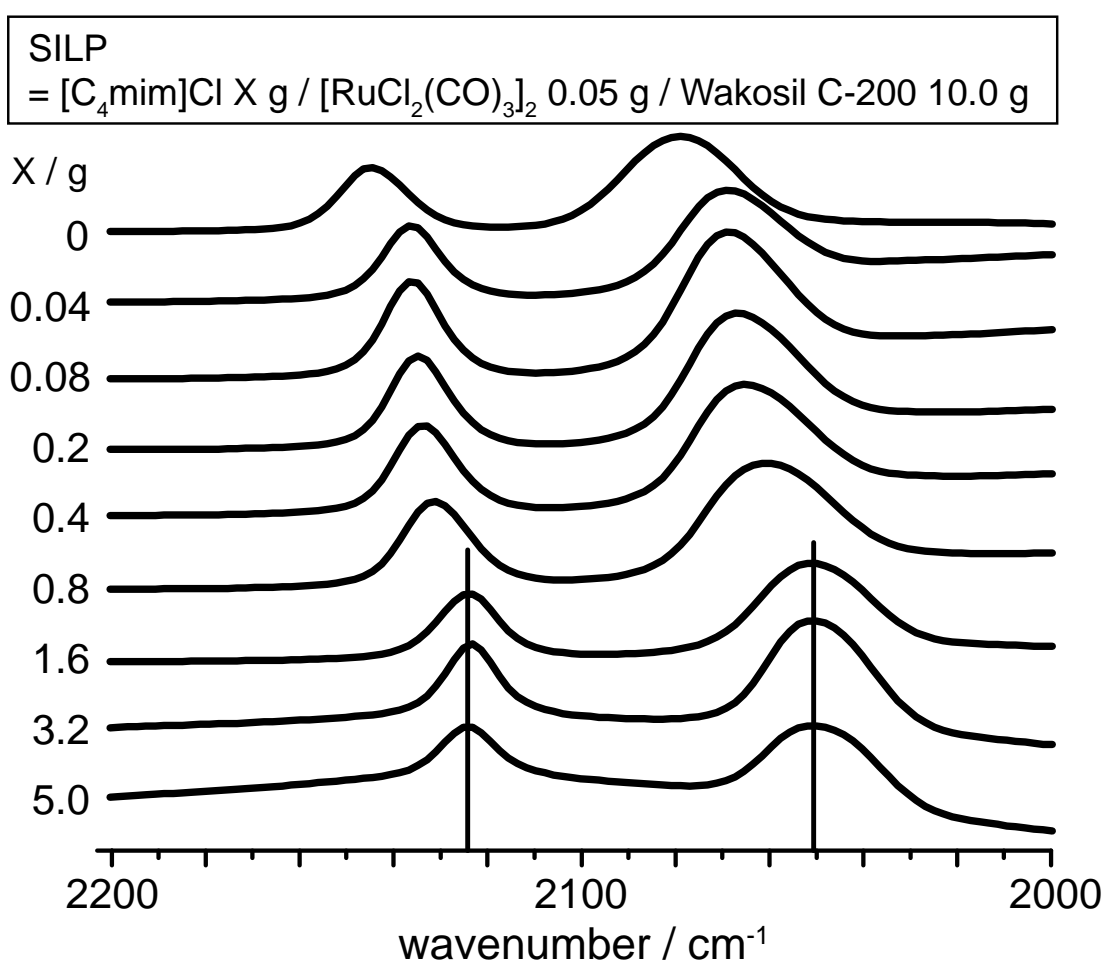

Figure 5 


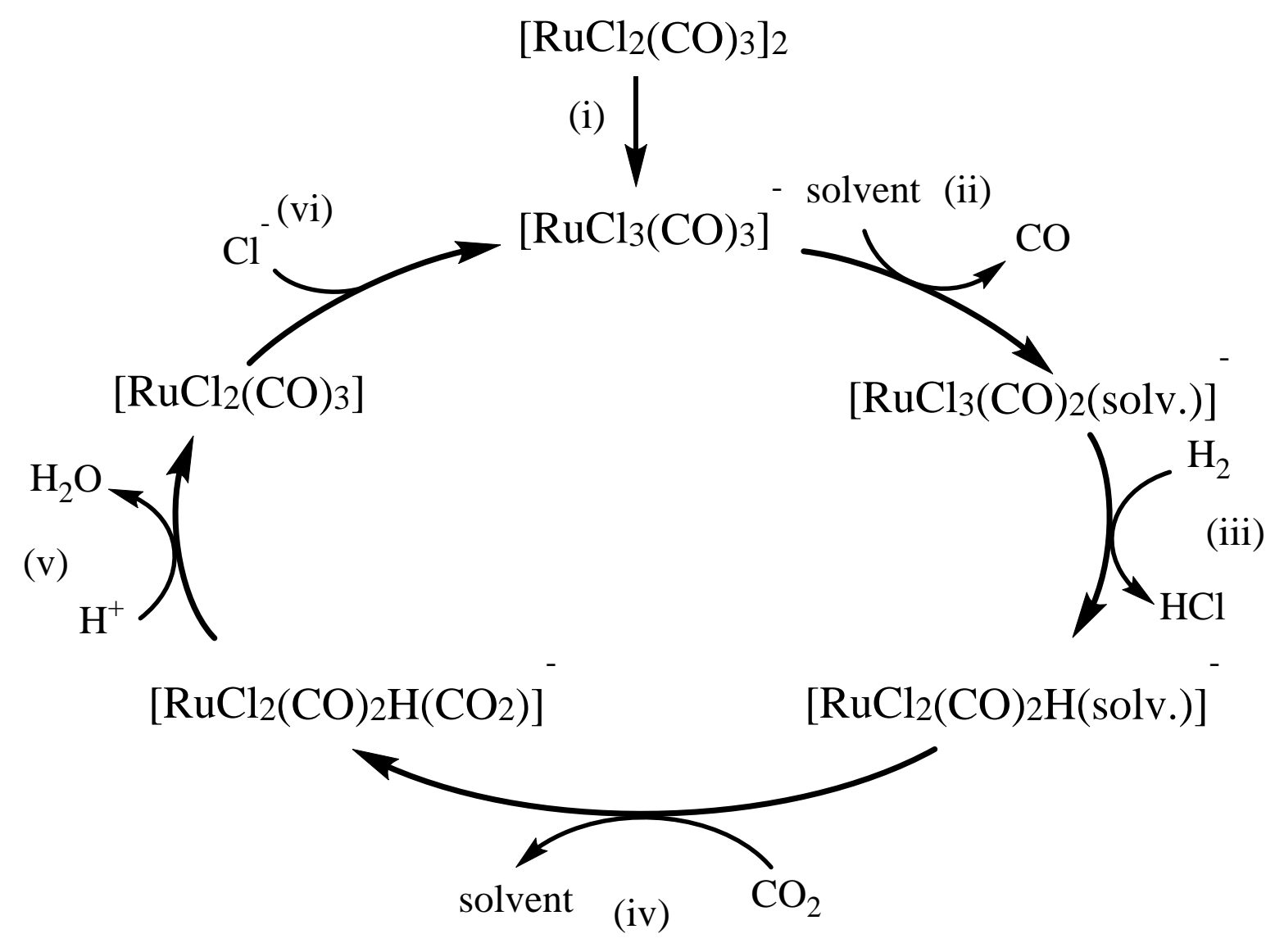

Figure 6 
(a) before treatment

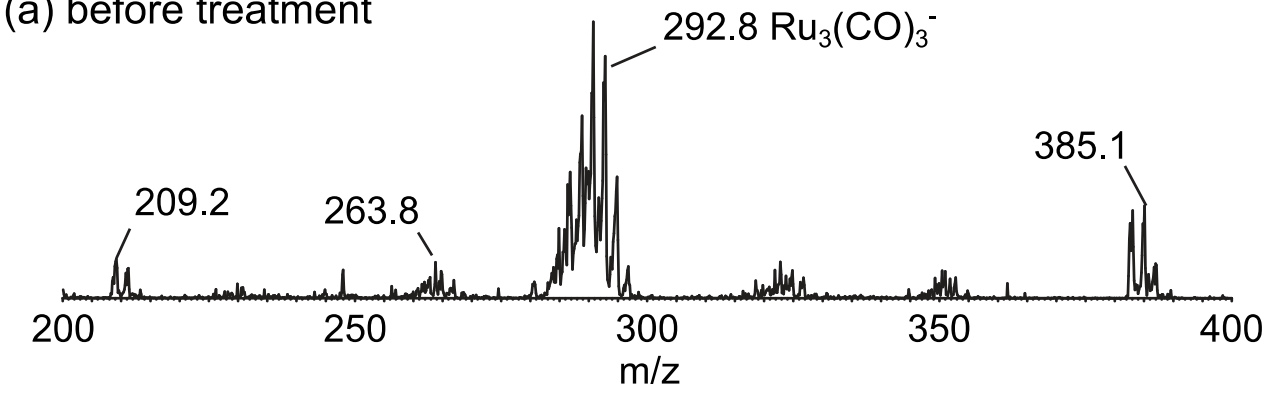

(b) $170{ }^{\circ} \mathrm{C}$ for $10 \mathrm{~h}$ under $\mathrm{N}_{2}\left(P_{\mathrm{N} 2}=2 \mathrm{MPa}\right)$

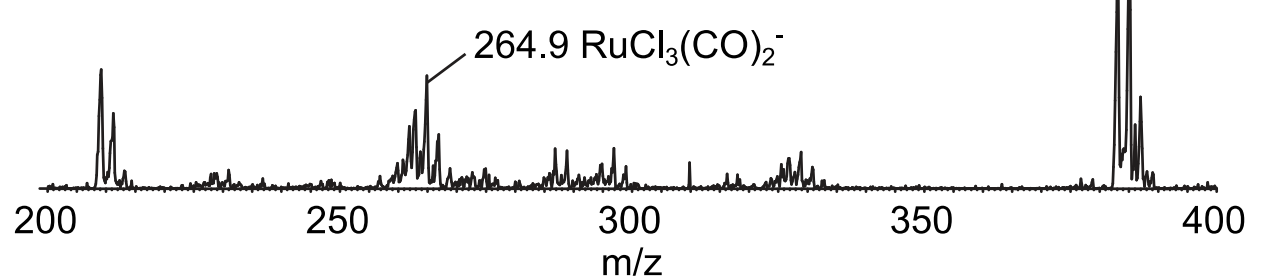

(c) $170{ }^{\circ} \mathrm{C}$ for $10 \mathrm{~h}$ under $\mathrm{H}_{2}\left(P_{\mathrm{H} 2}=2 \mathrm{MPa}\right)$

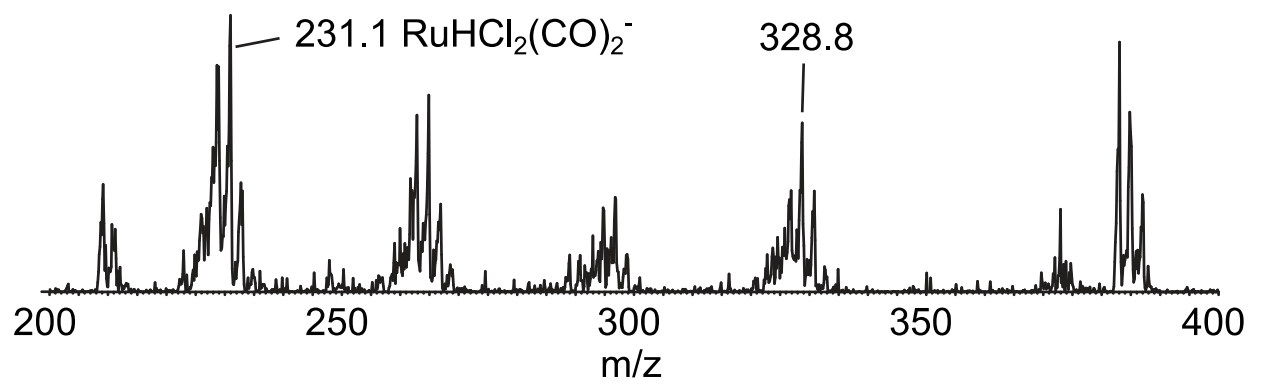

(d) $170{ }^{\circ} \mathrm{C}$ for $10 \mathrm{~h}$ under $\mathrm{CO}_{2} / \mathrm{H}_{2}\left(P_{\mathrm{CO} 2} / P_{\mathrm{H} 2}=2 \mathrm{MPa} / 6 \mathrm{MPa}\right)$

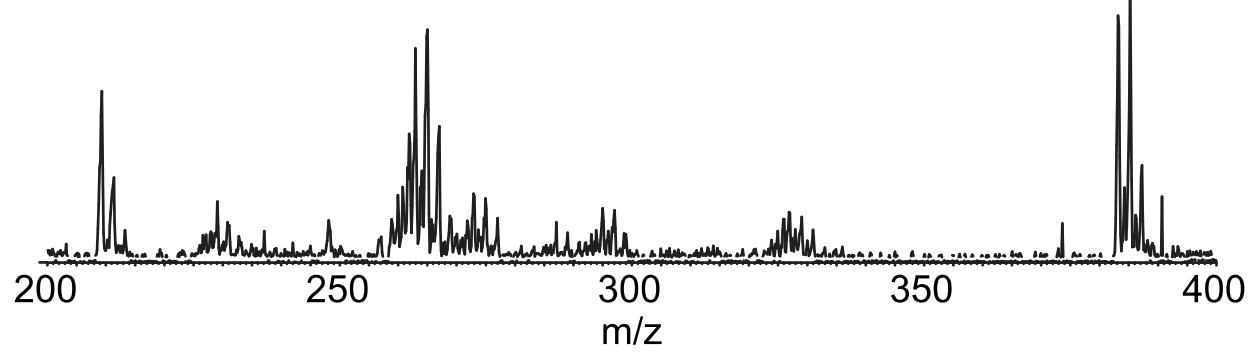

Figure 7 
(a) Homogeneous : [ $\left.\mathrm{C}_{4} \mathrm{mim}\right] \mathrm{Cl}(160 \mathrm{mg}), 170{ }^{\circ} \mathrm{C}$

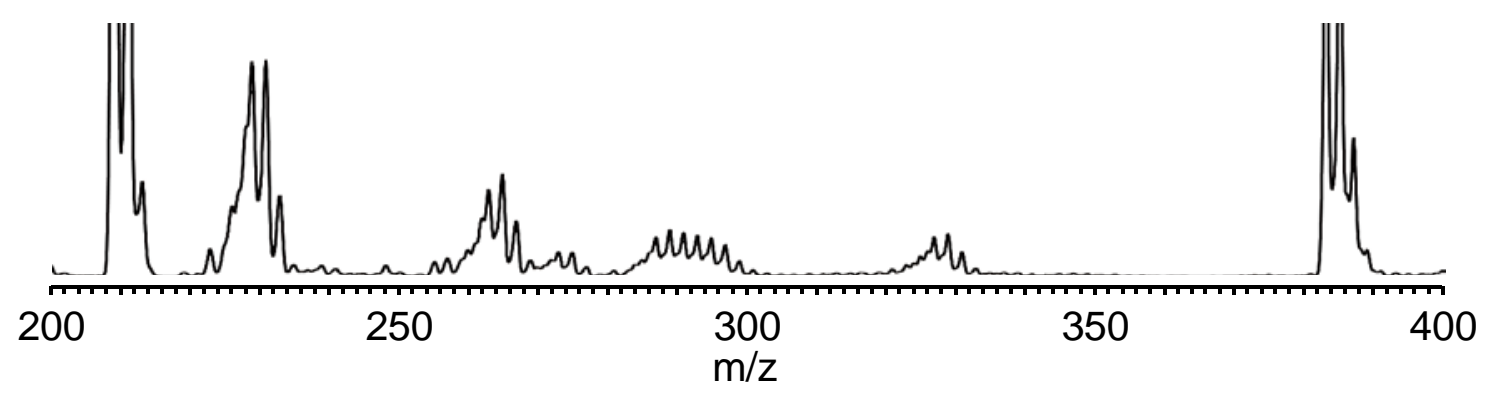

(b) SILP-CI (1.6) : $170^{\circ} \mathrm{C}$

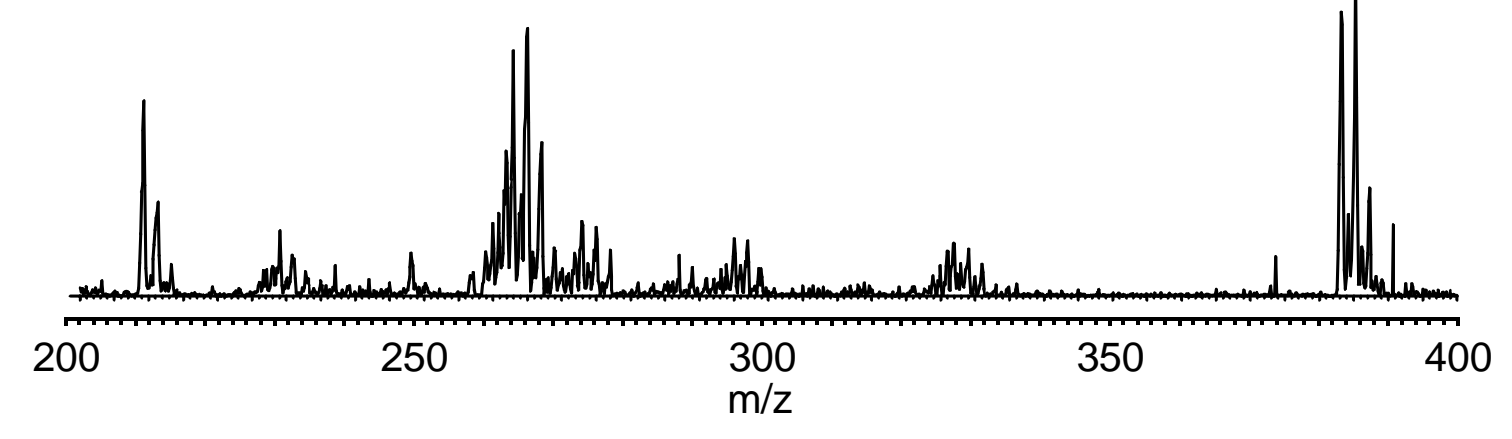

Figure 8 


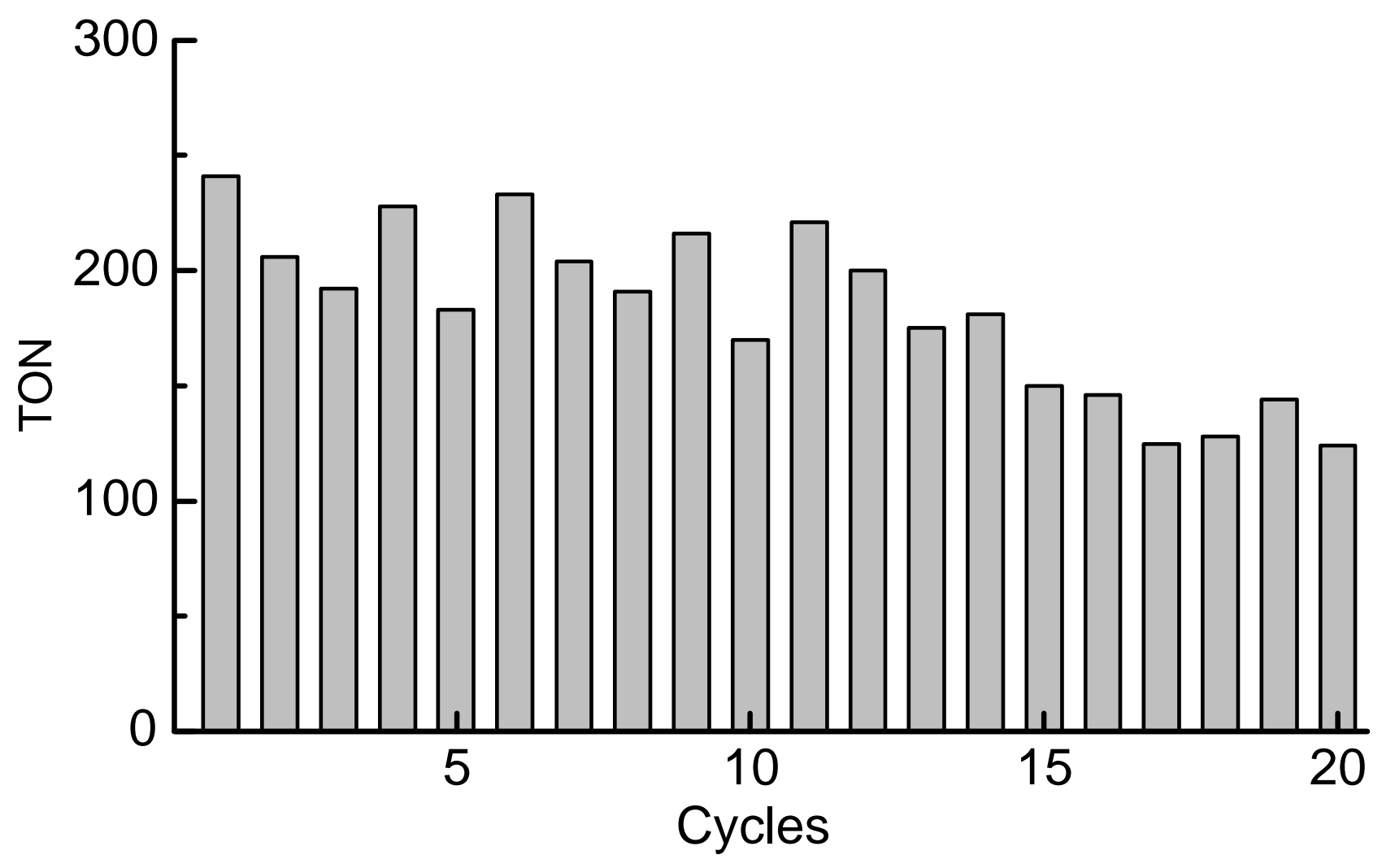

Figure 9 